\title{
CHARACTERISTICS OF HIPROLY BARLEY I. ISOLATION AND CHARACTERISATION OF TWO WATER-SOLUBLE HIGH-LYSINE PROTEINS
}

by

\author{
IB JONASSEN
}

\author{
Department of Biotechnology, Carlsberg Research Laboratory, \\ Gamle Carlsberg Vej 10, DK-2500 Copenhagen Valby \\ and \\ Institute of Genetics, University of Copenhagen, \\ Øster Farimagsgade 2A, DK-1353 K.
}

Keywords: Antibody production, antigenicity, molecular weight, isoelectric point, albumin.

The water-soluble albumin of the high-lysine barley called Hiproly was fractionated by means of ion exchange chromatography and gel filtration. Three high-lysine fractions were isolated, and from the chromatographic profiles it was deduced that two of these contribute prominently to the overall high lysine content of Hiproly albumin. The two polypeptides were purified, and antisera raised against them. Immunological cross reaction was observed suggesting that the smaller polypeptide with a molecular weight of 8,100 dalton is a fragment of the larger one with a molecular weight of 9.100 dalton. The fragment contains 6 and the larger polypeptide 8 lysine residues. Both proteins lacked cysteine, but were rich in valine, glutamine/glutamic acid and asparagine/ aspartic acid.

\section{INTRODUCTION}

In 1969 Munck et al. (18) reported the presence of a spontaneous high-lysine barley mutant in the World Barley Collection. The barley was of Ethiopian origin and named "Hiproly « because of its high lysine and high protein content. Fractionation of the crude protein of the Hiproly grain into various solubility classes revealed that the high-lysine content is partly due to an increased content of lysine rich albumin and globulin polypeptides (water- and salt-soluble proteins, respectively) and partly to an increased content of lysine in the glutelin fraction (alkali-soluble proteins).

Abbreviations: $\mathrm{BSA}=$ bovine serum albumin. SP II A and SP II B = lysine rich albumin polypeptides. 
It has been shown (18) that the high-lysine character is due to a single recessive gene. Munck (17) reported that $F_{4}$ lines from the cross Hiproly $\times$ normal lysine barley could be classified into three groups: normal lysine, elevated lysine, and high lysine. Grain hardness and cohesiveness of starch with the matrix protein (18) were also found to be characteristic for the high-lysine segregants, but there are different opinions as to whether or not these properties are due to a pleiotropic effect (16) or to another gene linked with the lys gene (10). Discelectrophoretic analyses of the water-soluble proteins of Hiproly (17) showed that 4 bands were markedly increased in the high-lysine barley when compared to the normal-lysine barley variety Kristina. Gel filtration analysis of the water- and salt-soluble proteins of Hiproly and of the commercial barley variety Carlsberg II (12) showed an increase in a high-lysine protein fraction with an apparent molecular weight of 30,000 dalton. Disc-electrophoresis separated this fraction into four bands all of which were increased in concentration in Hiproly.

The multiple effects of the lys gene makes it desireable to define its action at the molecular level. As a first step two high-lysine watersoluble proteins were purified and immunochemical assays developed for these proteins.

\section{MATERIALS AND METHODS}

\subsection{Plant material}

Hordeum vulgare variety Hiproly was a kind gift from fil.kand. A. TallberG, The Swedish Seed Association, Svalöf, Sweden, and grown at Carlsberg Plant Breeding's farm »Hyldagergård" in the summer of 1978 .

\subsection{Chemicals and proteins}

$8 \mathrm{~m}$ - and $6 \mathrm{~m}$-urea solutions were deionized on an ion-exchange column (AG-501X8, Bio-Rad Laboratories, Richmond, Calif., U.S.A.) immediately before use. Freund's complete and incomplete adjuvants were obtained from Difco laboratories, Detroit, Michigan, U.S.A. Sepha$\operatorname{dex}$ G 25 Medium, G 50 Superfine and G 75 Superfine were from Pharmacia Fine Chemicals, Uppsala, Sweden. DEAE- and CM-cellulose types DE-52 and CM-52 were from Whatman, Maidstone, England. Carrier ampholytes, Ampholine $\mathrm{pH} \mathrm{5-7,} \mathrm{were} \mathrm{obtained} \mathrm{from} \mathrm{LKB,}$ Bromma, Sweden. Cytochrome C, ribonuclease A, myoglobin, $\alpha$-chymotrypsinogen A, ovalbumin and bovine serum albumin were obtained from Sigma Chemical Co., St. Louis, MO., U.S.A. Pepsin was from Merck, Darmstadt, Germany. Unless otherwise specified, all other chemicals were of analytical grade and were used without further purification.

\subsection{Equipment}

Column eluates were monitored at $280 \mathrm{~nm}$ with an LKB Uvicord II and the absorbance at $280 \mathrm{~nm}$ of the individual fractions measured in a Jasco Uvidec-1 spectrophotometer. Isoelectric focusing was performed using LKB 8101 equipment.

\subsection{Sodium dodecyl sulphate polyacrylamide gel electrophoresis}

Two different analytical slab gel electrophoretic systems were employed. The first was a 1 $\mathrm{mm}$ thick $11 \%$ gel slab using the discontinuous alkaline buffer system of Nevilue (19). The second was a $1 \mathrm{~mm}$ thick $7.5-15 \%$ gradient of polyacrylamide as described by CHUA and BENNOUN (6). All samples were prepared as described in (6).

\subsection{Amino acid analyses}

Two methods of amino acid analysis were employed. All hydrolysates obtained were analysed on a Durrum D-500 amino acid analyzer.

\subsubsection{Amino acid analysis of protein fractions}

Protein fractions were analysed as duplicate samples, each containing $1 \mathrm{mg}$ protein. The samples were hydrolysed in $0.2 \mathrm{ml} 6 \mathrm{M}-\mathrm{HCl}$ containing $0.05 \%$ phenol for 24 hours at $110^{\circ} \mathrm{C}$ in evacuated ampoules. Values for the amino acid content are expressed as means of the duplicate determinations.

\subsubsection{Amino acid analysis of pure proteins}

Hexaplicate samples containing $0.030 \mathrm{mg}$ protein were hydrolysed in $0.1 \mathrm{ml} 6 \mathrm{M}-\mathrm{HCl}$ 
containing $0.05 \%$ phenol. Hydrolysis was carried out at $110^{\circ} \mathrm{C}$ in evacuated ampoules for 24 . 48 , and 72 hours. Values for valine and isoleucine are those for 72 hours hydrolysis. Cysteine was determined as cysteic acid after performic acid oxidation as described by HiRs (11). Values for threonine and serine were obtained after extrapolation to 0 -hours hydrolysis. Tryptophane was determined from the tyrosine/tryptophane ratio by the method of BENZE and SCHMID (3). Values of all other amino acids are expressed as an average for the total of 6 values for each polypeptide.

\subsection{Preparation of water-soluble protein}

The water-soluble albumin fraction as defined by OsBorne (20) was isolated as follows. Barley. (cv. Hiproly) was ground in a Cyclotec sample mill (Udy Analyzer Company, Boulder. Colorado, U.S.A.) using a $1 \mathrm{~mm}$ screen. The flour was defatted with acetone as described by IINGVERSEN and KøIE (13). All subsequent procedures were performed at $4^{\circ} \mathrm{C}$. Defatted flour $(150 \mathrm{~g})$ was extracted by stirring for 1 hour with $0.0025 \mathrm{M}$-NaEDTA, $0.0025 \mathrm{M}$-1-ascorbic acid, and $0.001 \mathrm{~m}$-dithiothreitol $(700 \mathrm{ml})$. The extract was clarified by centrifugation at $27,000 \times \mathrm{g}$ for $25 \mathrm{~min}$ and allowed to stand at $4{ }^{\circ} \mathrm{C}$ for two days to reduce the viscosity $(15)$. Precipitated protein was then removed by centrifugation $(27,000 \times \mathrm{g}, 25 \mathrm{~min})$ and the clarified extract was subjected to Sephadex G 25 chromatography to remove salts and polyphenols, as recommended by StrøBAK and GibBONS (22). Due to the decrease in salt concentration, contaminating globulin precipitated, and could be removed by centrifugation $(27,000 \times \mathrm{g}, 25$ $\mathrm{min})$. The resultant extract was lyophilized; the final yield being $4 \mathrm{~g}$ (26 mg. $\mathrm{g}^{-1}$ defatted flour).

\subsection{Isolation of albumin proteins}

Isolation and purification of albumin proteins were carried out according to the flow-sheet in Figure 1.

\subsubsection{Fractionation with DEAE-cellulose}

DEAE-cellulose chromatography was performed at $4{ }^{\circ} \mathrm{C}$ using a modified version of the technique described by El-Negomy et al. (8). A

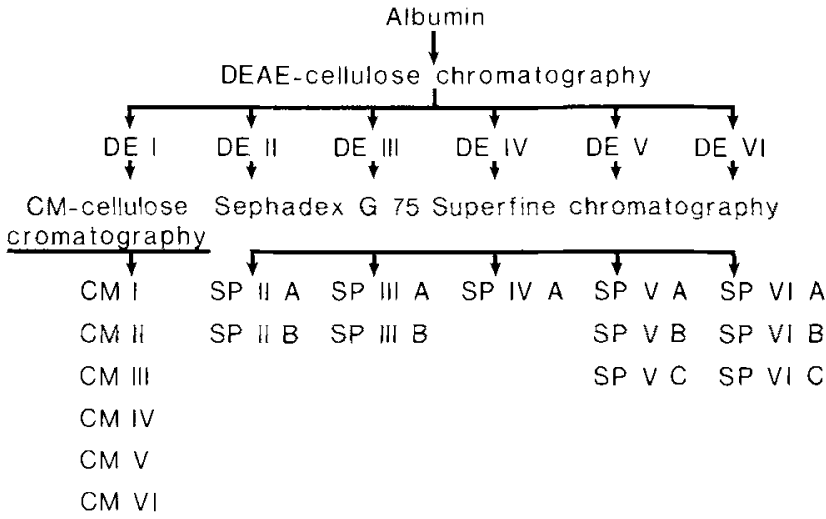

Figure 1. Fractionation of the water soluble protein of Hiproly barley as outlined in section 2.7 has been summarized in the Figure.

$2.6 \times 43 \mathrm{~cm}$ column of DEAE-cellulose was equilibrated with elution buffer $(0.001 \mathrm{M}$ dithiothreitol, 0.03 m-glycin- $\mathrm{NaOH}$ pH 8.1). Albumin $(1.5 \mathrm{~g})$ was dissolved in $200 \mathrm{ml}$ elution buffer and applied to the column which was subsequently subjected to a linear gradient of $\mathrm{NaCl}(0.0-0.12 \mathrm{~m})$ in elution buffer at a flow rate of $1.1 \mathrm{ml}$.hour ${ }^{-1}$, and $20 \mathrm{ml}$ fractions were collected. Protein fractions were pooled according to the peaks in the elution profile, dialyzed, and concentrated using an Amincon $\mathrm{CH}_{3}$ concentrator fitted with a HIPIO membrane. The concentrated fractions were lyophylized.

\subsubsection{Fractionation with $C M$-cellulose}

Peak DE I obtained from the DEAE-cellulose chromatography was subjected to $\mathrm{CM}$-cellulose chromatography at $4^{\circ} \mathrm{C}$ : $200 \mathrm{mg}$ lyophilized protein was dissolved in $12 \mathrm{ml}$ elution buffer (0.001 M-dithiothreitol, $0.02 \mathrm{~m}$-phosphate buffer, $\mathrm{pH} 6.50$ ) and applied to a $0.9 \times 50 \mathrm{~cm} \mathrm{CM}$ cellulose column equilibrated with the same buffer. Elution was performed with a linear gradient of $\mathrm{NaCl}(0.0-0.14 \mathrm{M})$ in the elution buffer at a flow rate of $9 \mathrm{ml} \cdot$ hour $^{-1}, 3 \mathrm{ml}$ fractions were collected. Fractions were bulked according to peaks in the elution profile, dialyzed, and lyophilized. Samples of each fraction were analysed by SDS gel electrophoresis and amino acid analysis.

\subsubsection{Sephadex $G 75$ superfine chromatography} Fractions (DE II-DE VI) from the DEAE- 
I. JONASSEN: Characteristics of Hiproly barley I.

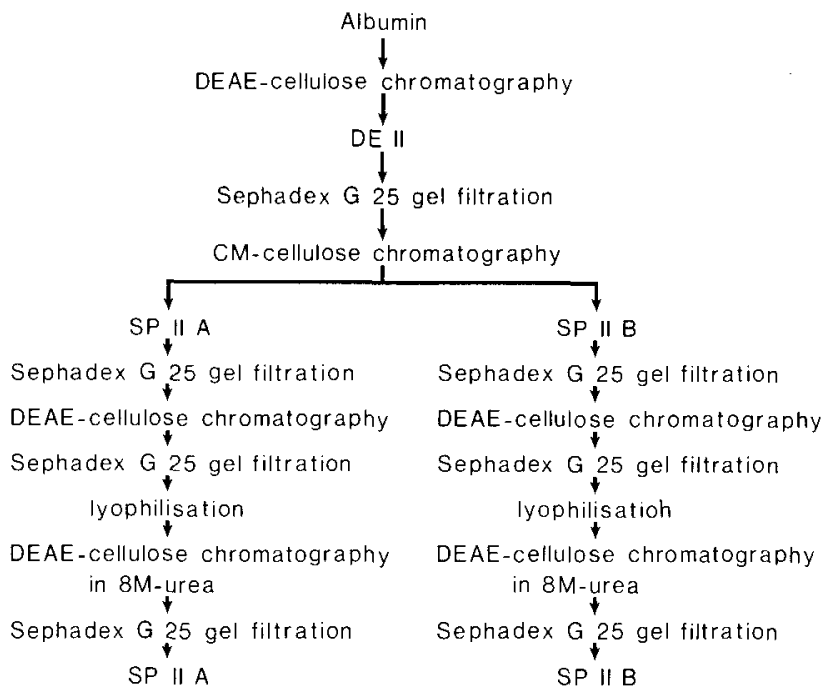

Figure 2. Purification of the two high-lysine proteins (SP II A and SP II B) of Hiproly albumin as outlined in section 2.8 has been summarized in the Figure.

cellulose separation were subjected to gel filtration on Sephadex G 75 Superfine. $20 \mathrm{mg}$ samples were dissolved in $1 \mathrm{ml}$ elution buffer $(0.0077$ м-NaN $3,0.05$ m-phosphate buffer, $\mathrm{pH}$ 8 ) and applied to a pre-equilibrated $1.6 \times 88 \mathrm{~cm}$ column of Sephadex G 75 Superfine. The flow rate was $2.4 \mathrm{ml} \cdot$ hour $^{-1}$, and $2.4 \mathrm{ml}$ fractions were collected. SDS gel electrophoresis and amino acid analysis were performed on aliquots of each major peak.

\subsection{Isolation of two lysine-rich proteins}

The isolation and purification procedure of the two lysine-rich proteins is outlined in Figure 2. DEAE-cellulose chromatography was carried out as described in section 2.7.1, but scaled up about 7 times: $11 \mathrm{~g}$ of albumin was dissolved in $1360 \mathrm{ml}$ elution buffer and applied to a $5.0 \times 78$ $\mathrm{cm}$ DEAE-cellulose column equilibrated with the same buffer. The sample was subjected to a linear gradient of $\mathrm{NaCl}(0.0-0.12 \mathrm{~m})$ in elution buffer at a flow rate of $360 \mathrm{ml} \cdot$ hour $^{-1}$ and $18 \mathrm{ml}$ fractions were collected. Each fraction within the second peak of the chromatogram (corresponding to DE II in Figure 1) was examined by SDS gel electrophoresis. Identical fractions from this second peak were pooled and reequilibrated
( $0.001 \mathrm{~m}$-dithiotreitol, $0.02 \mathrm{M}$-acetate, $\mathrm{pH} 4.5$ ) by gel filtration on Sephadex G 25. The sample was then applied to a $1.6 \times 72 \mathrm{~cm}$ column of CMcellulose equilibrated with sample buffer. The column was eluted with a linear gradient of $\mathrm{NaCl}(0.0-0.3 \mathrm{M})$ in the same buffer at a flow rate of $40 \mathrm{ml}$ hour ${ }^{-1}$, and $6.6 \mathrm{ml}$ fractions were collected. Fractions corresponding to protein peaks were pooled, desalted on Sephadex G 25, and lyophilized. The lyophilized protein was analysed by isoelectric focusing as described in section 2.10. Final purification of the two lysinerich proteins was achieved by DEAE-cellulose chromatography in the presence of $8 \mathrm{M}$-urea. 50 $\mathrm{mg}$ samples were dissolved in $2 \mathrm{ml}$ elution buffer and applied to a $0.9 \times 55 \mathrm{~cm}$ DEAE-cellulose column equilibrated with elution buffer $(0.001$ M-dithiotreitol, 8 M-urea, 0.03 m-glycine- $\mathrm{NaOH}$, $\mathrm{pH} 8$ ). Elution was achieved with a gradient of $\mathrm{NaCl}(0.0-0.05 \mathrm{M})$ in elution buffer at a flow rate of $90 \mathrm{ml}$ hour ${ }^{-1}$, and $1.5 \mathrm{ml}$ fractions were collected. Each fraction was analysed by SDS gel electrophoresis and the buffer was exchanged to $0.1 \mathrm{~m}-\mathrm{NH}_{4} \mathrm{HCO}_{3}$ by gel-filtration on Sephadex $\mathrm{G}$ 25 . The resulting protein solutions were lyophilized.

\subsection{Molecular weight determinations}

Molecular weight determinations were performed on Sephadex G 50 Superfine as described by ANDREws (1) and by SDS gel electrophoresis. For gel filtration, $2 \mathrm{mg}$ samples were dissolved in $1 \mathrm{ml}$ of elution buffer $(0.05 \mathrm{M}$-phosphate buffer, $\mathrm{pH} 8$, containing $0.45 \mathrm{M}-\mathrm{NaCl}$ ) and applied to a pre-equilibrated $1.6 \times 91 \mathrm{~cm}$ column of Sephadex G 50 Superfine. The flow was 2.85 $\mathrm{ml} \cdot$ hour $^{-1}$, and $2.85 \mathrm{ml}$ fractions were collected. Molecular weight was determined as the average of two determinations.

\subsection{Isoelectric focusing}

Isoelectric focusing was carried out at $7^{\circ} \mathrm{C}$ for three days on an expanded gradient of $\mathrm{pH} 5-7$. The $\mathrm{pH}$ gradient was eluted at a rate of 2 $\mathrm{ml} \cdot \mathrm{min}^{-1}$, and $2 \mathrm{ml}$ fractions were collected. The transmission at $280 \mathrm{~nm}$ of the eluate was recorded. 


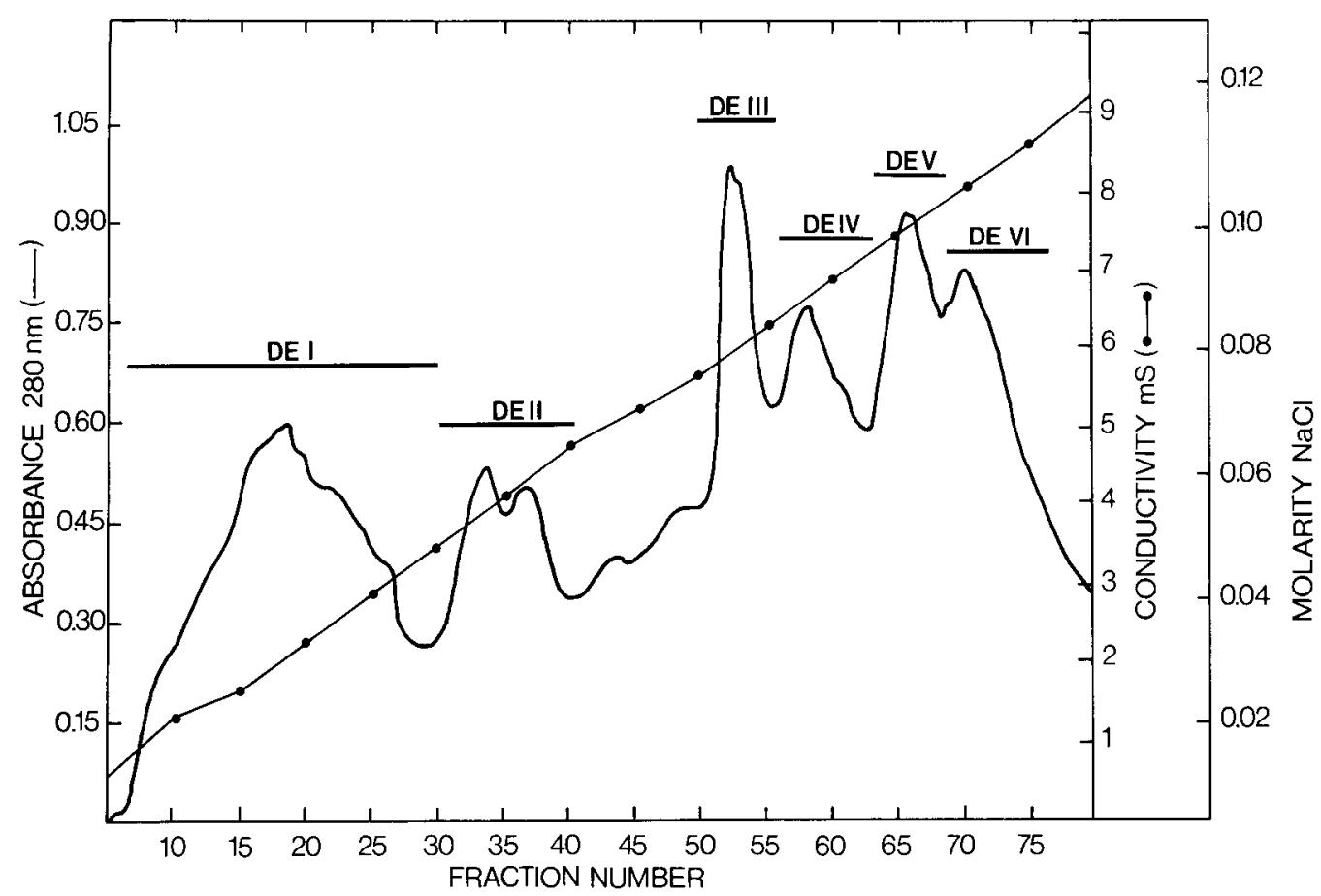

Figure 3. Elution profile of DEAE-cellulose chromatography of $1.5 \mathrm{~g}$ albumin as outlined in section 2.7.1. Appropriate fractions were pooled and designated as indicated by the horizontal bars.

\subsection{Determination of carbohydrate}

The method of Dubors et al. (7) was used with the following modifications: $0.8 \mathrm{ml}$ samples containing $2.5 \mathrm{mg} \cdot \mathrm{ml}^{-1}$ of protein were added $0.04 \mathrm{ml} 80 \% \mathrm{w} / \mathrm{v}$ phenol, the samples were mixed, and $2 \mathrm{ml}$ of concentrated $\mathrm{H}_{2} \mathrm{SO}_{4}$ were added. Samples were incubated at $100^{\circ} \mathrm{C}$ for 10 min. The absorbance at $490 \mathrm{~nm}$ was measured against a blank lacking sugar. Results were expressed as glucose equivalents.

\subsection{Preparation and purification of antiserum against purified high-lysine proteins}

Antibodies were raised against isolated proteins polymerized with glutaraldehyde as described by Bollum (4), and the degree of polymerization was determined by SDS gel electrophoresis. 6 rabbits were treated using BoLLuM's immunization schedule, and 3 using a schedule devised by HarboE and INGiLd (9). The antisera obtained were purified as recommended by HARBOE and INGILD (9).

\subsection{Immunoelectrophoretic techniques}

Crossed immunoelectrophoresis and tandem crossed immunoelectrophoresis was carried out as described by AxersEN et al. (2).

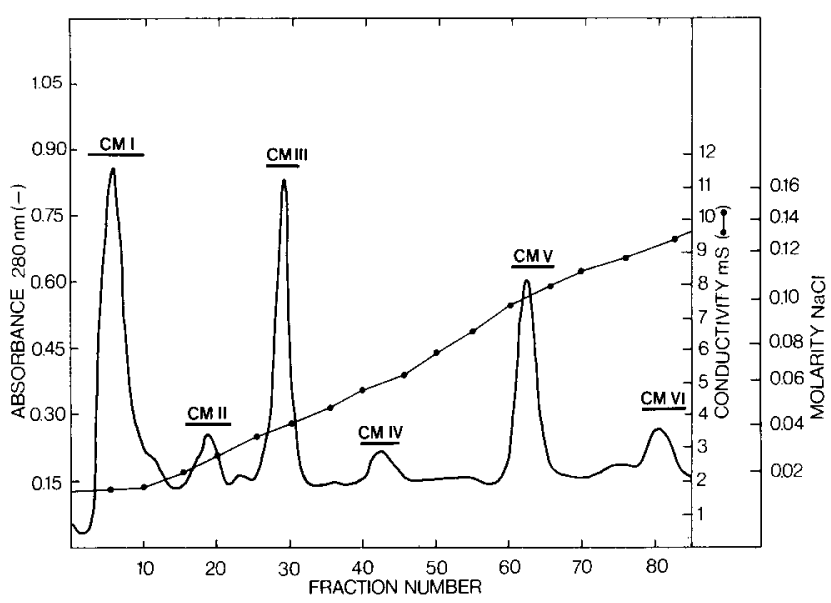

Figure 4. Elution profile of CM-cellulose chromatography of $200 \mathrm{mg}$ lyophilized protein obtained from fraction DE I as outlined in section 2.7.2.

Appropriate fractions were pooled and named as indicated by the horizontal bars. 
I. JONASSEN: Characteristics of Hiproly barley I.

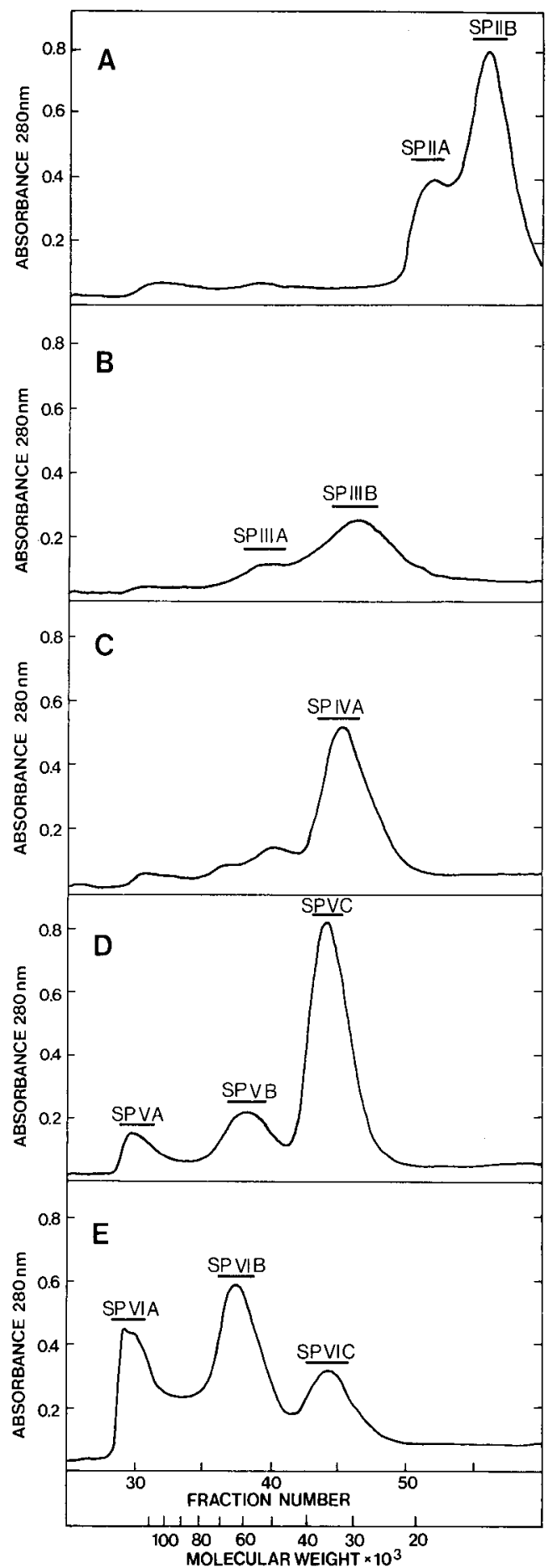

Figure 5. Elution profiles of Sephadex G 75 Superfine gel filtration of the fractions DE II to DE VI obtained by DEAE-cellulose chromatography (Figure 3) as outlined in section 2.7.3.

Appropriate fractions were pooled and named as indicated by the horizontal bars. A to E correspond to fraction DE II to DE VI of Figure 3.

\section{RESULTS AND DISCUSSION}

\subsection{Demonstration of high-lysine proteins in barley (cv. Hiproly) albumin}

Hiproly albumin was separated by DEAEcellulose ion-exchange chromatography into six fractions designated DE I to DE VI (Figure 3). The DE I fraction separated on a CM-cellulose ion exchange column into six peaks (Figure 4). Fractions DE II to DE VI were subjected to Sephadex gel filtration and yielded in all, 11 well defined fractions designated with the letters SP. (Figure 5). Amino acid analysis of the individual fractions (Table I) revealed three fractions with a high content of lysine, namely fractions CM VI, fraction SP II A and SP II B. Fraction CM VI contained 8 mole \% lysine and consisted of a single protein with a molecular weight of 30,000 dalton as determined by SDS gel electrophoresis. The elution behaviour of this component on CMcellulose indicated a protein with a high isoelectric point. The two peaks combined in fraction DE II ( 7.1 mole \% lysine) could be resolved by gel filtration into SP II A and SP II B. The latter contained 8.4 and 8.6 mole \% lysine, respectively (Figures 3 and 5A). SDS gel electrophoresis of these fractions revealed one major protein in each peak with a molecular weight below 10,000 dalton, but the major protein in SP II A appeared to be the larger of the two. The fractions from the DEAE-cellulose column were eluted with glycine buffer and dialysed. Amino acid analyses revealed that contaminating glycine buffer still was present in the fractions. This is reflected in a high content of glycine in the fractions DE I to DE VI. As that also lowered the mole percentage of lysine it explains why the lysine content of fraction DE II is increased after gel filtration to produce fraction SP II A and SP II B. (Table I).

It can be deduced from the absorption profile of Figure 4 that fraction CM VI only constitutes a minor part of fraction DE I. On the other hand fractions SP II A and SP II B constitute (Figure 5A) nearly all of fraction DE II. This is also reflected in the lysine content of fraction DE I with a value of 4.2 mole $\%$ and that of DE II with a value of 7.1 mole \%. Fraction DE II thus contains two proteins which contribute very substantially to the overall lysine content of the Hiproly barley albumin. 
Table I.

Mole \% lysine in the albumin fractions obtained

\begin{tabular}{llllll}
\hline \multicolumn{2}{c}{$\begin{array}{c}\text { DEAE-cellulose } \\
\text { chromatography }\end{array}$} & \multicolumn{2}{c}{$\begin{array}{c}\text { CM-cellulose } \\
\text { chromatography }\end{array}$} & \multicolumn{2}{c}{$\begin{array}{c}\text { gel filtration } \\
\text { (Sephadex G 75 Superfine) }\end{array}$} \\
\hline DE I & 4.2 & CM I & 4.8 & SP II A & 8.4 \\
DE II & 7.1 & CM II & 3.6 & SP II B & 8.6 \\
DE III & 4.3 & CM III & 4.4 & SP III A & 5.0 \\
DE IV & 5.3 & CM IV & 4.2 & SP III B & 5.4 \\
DE V & 5.2 & CM V & 4.2 & SP IV A & 6.5 \\
DE VI & 4.7 & CM VI & 8.0 & SP V A & 5.2 \\
& & & & SP V B & 5.0 \\
& & & & SP V C & 6.3 \\
& & & & SP VI A & 5.2 \\
& & & & SP VI B & 5.0 \\
& & & & & \\
\hline
\end{tabular}

\subsection{Purification and isolation of two lysine- rich proteins}

In order to produce larger amounts of purified SP II A and SP II B proteins for physical and chemical characterisation the isolation procedure described in section 2.8 and Figure 2 was employed. Change of buffers was consistently performed by gel filtration instead of cellophane membranes in order to minimize loss of material due to the low molecular weight of the two proteins. CM-cellulose chromatography was used for concentration of fraction DE II and its separation into SP II A and SP II B (Figure 6). The final DEAE-cellulose chromatography was performed in the presence of $8 \mathrm{M}$-urea in order to avoid aggregation (Figure 7). The yield of SP II A exceeded on the average the yield of SP II B by 1.4 fold.

The protein corresponding to fraction SP II B resulted in only one band on SDS gel electrophoresis (Figure 9B) while in the SP II A protein preparation, a small contamination of slightly lower molecular weight could be detected (Figure 9A). The effect of this contamination on immunological purity will be considered in section 3.4 .

\subsection{Physical and chemical characterisation of two high-lysine proteins}

The molecular weight of the two proteins was calculated on the basis of their amino acid composition (Table II). SP II A consisted of 82 residues corresponding to a molecular weight of 9,146 dalton, while SP II B contained 71 residues yielding a molecular weight of 8,089 dalton.

Carbohydrate determination as described in section 2.11, indicated that the protein SP II A contained about $1 \%$ glucose or glucose equivalent, while the protein SP II B contained no carbohydrate. This in part explains the behaviour of the two proteins on gel filtration (Sephadex G 50 Superfine) and SDS gel electrophoresis. Gel filtration and SDS gel electrophoresis tend to

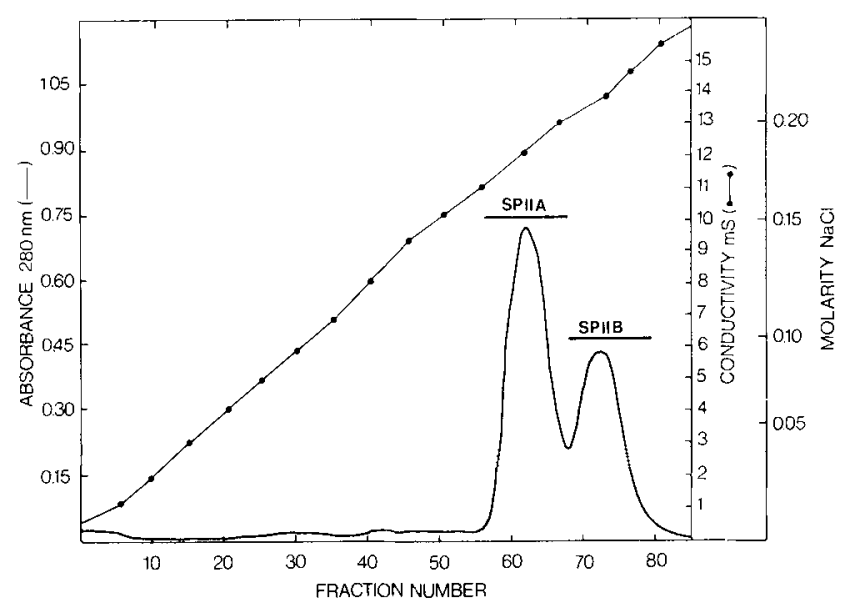

Figure 6. Preparative CM-cellulose chromatography of $502 \mathrm{mg}$ of the DE II albumin fraction (section 2.8.).

Appropriate fractions were pooled and named as indicated by the horizontal bars. 


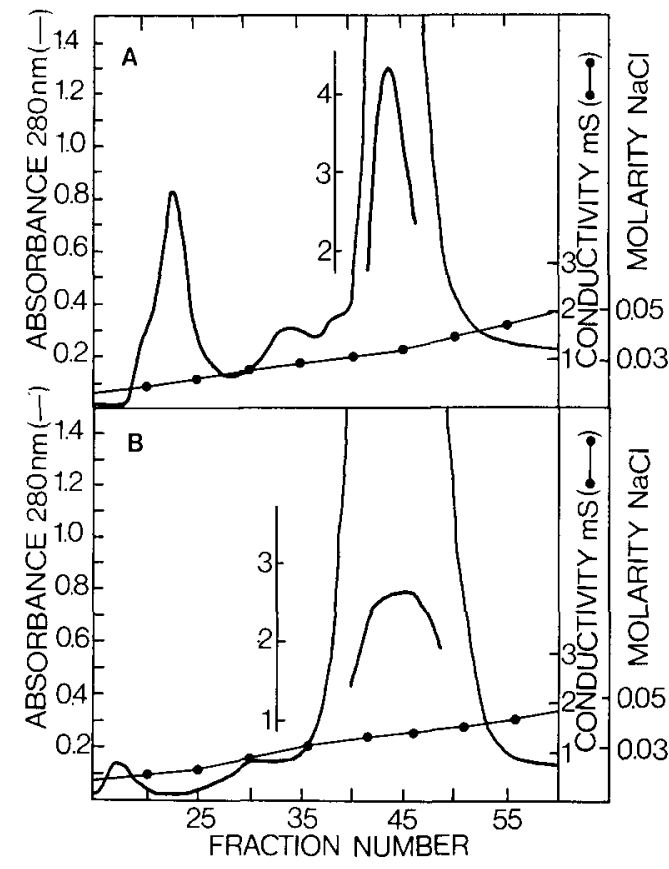

Figure 7. Final purification of SP II A and SP II B (section 2.8.) by DEAE-cellulose chromatography in the presence of $8 \mathrm{M}$-urea.

The OD of the inset is expressed on a compressed scale. A) Ion exchange chromatography of $50 \mathrm{mg} \mathrm{SP}$ II A protein. B) Ion exchange chromatography of 50 mg SP II B protein.

overestimate the molecular weight of SP II A (12,000 and 10,500 dalton, respectively), whereas SP II B gave a value of 9,000 dalton by SDS gel electrophoresis which is close to the molecular weight determined by amino acid analysis. SP II $\mathrm{B}$ protein gave an unexpected low value of 5,000 dalton when analysed by gel filtration.

Both proteins were rich in valine, glutamine/ glutamic acid, lysine and aspargine/aspartic acid but lacked cysteine (Table II). It has been shown that Hiproly is richer in lysine, arginine, and valine and deficient in cysteine when compared

Table II.

Amino acid composition of SP II A and SP II B proteins from Hiproly albumin.

\begin{tabular}{|c|c|c|c|c|}
\hline \multirow{3}{*}{ Amino acid } & \multicolumn{4}{|c|}{ Residues per molecule } \\
\hline & \multicolumn{2}{|c|}{ Experimental values } & \multicolumn{2}{|c|}{ Nearest integer } \\
\hline & SP II A & SP II B & SP II A & SP II B \\
\hline Asx & 7.8 & 7.1 & 8 & 7 \\
\hline Thr & $3.8^{\mathrm{a} !}$ & $3.2^{\mathrm{a} !}$ & 4 & 3 \\
\hline Ser & $3.2^{\mathrm{a})}$ & $1.1^{\mathrm{a})}$ & 3 & 1 \\
\hline Glx & 11.45 & 10.3 & 11 & 10 \\
\hline Pro & 4.8 & 4.2 & 5 & 4 \\
\hline Gly & 5.9 & 3.8 & 6 & 4 \\
\hline Ala & 4.0 & 3.4 & 4 & 3 \\
\hline Val & $11.2^{b)}$ & $10.9 \mathrm{~b})$ & 11 & 11 \\
\hline Met & 1.0 & 1.0 & 1 & 1 \\
\hline Ile & $5.59 \mathrm{~b})$ & $6.0^{\mathrm{bl}}$ & 6 & 6 \\
\hline Leu & 5.8 & 6.4 & 6 & 6 \\
\hline Tyr & 1.0 & 1.1 & 1 & 1 \\
\hline Phe & 1.0 & 1.0 & 1 & 1 \\
\hline His & 0.8 & 0.9 & 1 & 1 \\
\hline Lys & 7.51 & 6.2 & 8 & 6 \\
\hline Arg & 4.9 & 4.9 & 5 & 5 \\
\hline Cys & $0^{c)}$ & $0^{\text {c) }}$ & 0 & 0 \\
\hline Trp & $0.8^{\mathrm{d})}$ & $0.8^{\mathrm{d})}$ & 1 & 1 \\
\hline Total number of residues & & & 82 & 71 \\
\hline Molecular weight & & & 9.146 & 8.089 \\
\hline
\end{tabular}

a) Extrapolated to zero-time of hydrolysis

b) Value of 72 hours hydrolysis

c) As cysteic acid

d) Determined spectrophometrically 
Table III.

Rabbit immunization scheme

\begin{tabular}{llll}
\hline Rabbit & Antigen & $\begin{array}{l}\text { Immunization } \\
\text { schedule } \\
\text { reference }\end{array}$ & $\begin{array}{l}\text { Precipitating } \\
\text { antibody } \\
\text { activity }\end{array}$ \\
\hline 1,2 & SP II A & $(9)$ & activity \\
3 & SP II A + BSA & $(9)$ & activity \\
$4,5,6$, & SP II B & $(4)$ & none \\
7,8, & SP II B & $(4)$ & activity \\
9 & SP II B,+ BSA & $(4)$ & none \\
\hline
\end{tabular}

to other barley varieties $(17,21)$. It is therefore of considerable interest to quantify SP II A and SP II B albumin in Hiproly versus other barley varieties in order to elucidate whether the deviating amino acid composition of Hiproly grains can in part be explained by a high content of SP II A and SP II B. This topic will be treated in a subsequent paper (14).

Isoelectric focusing was performed as described in section 2.10 and yielded a pI of 5.94 and 7.02 for SP II A and SP II B, respectively. A pronounced aggregation was observed during isoelectric focusing, and the experiment was repeated in the presence of $6 \mathrm{~m}$-urea which prevents protein aggregation but lowers the activity of $\mathrm{H}^{+}$(5). The isoelectric points measured in the presence of $6 \mathrm{M}$-urea were increased to 6.34 and 7.40 for SP II A and SP II $\mathrm{B}$, respectively, which is in good agreement with the results reported by $U_{I}$ (23). Aggregation of the two high-lysine proteins was also observed during fractionation (Figure $5 \mathrm{~A}$ ) where dimers were observed. This pronounced tendency for aggregation could explain why INGVERSEN and KøIE (12) identified a high-lysine fraction of molecular weight of 30,000 dalton in their gel filtration experiments with Hiproly.

\subsection{Immunochemistry and immunisation}

Rabbit antiserum produced against a crude salt extract of Hiproly barley (albumin and globulin) was used without success for crossed immunoelectrophoresis versus SP II A and SP II

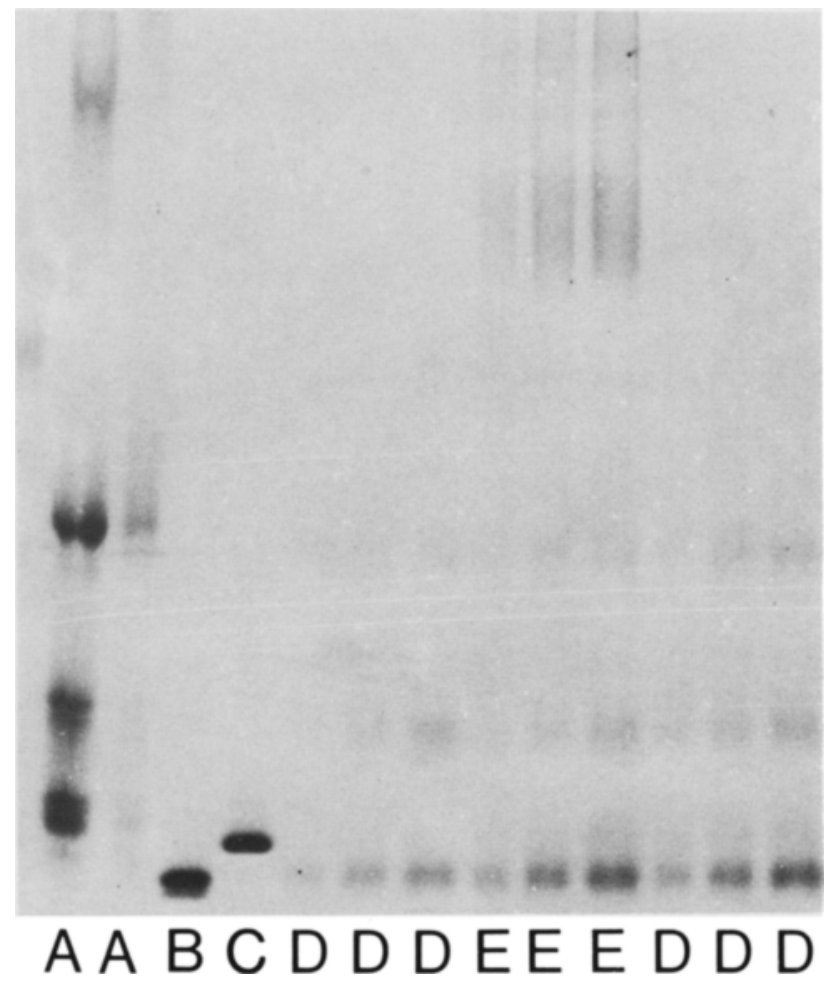

Figure 8. SDS gel electrophoresis of SP II B antigen preparations.

A: Molecular weight standards $(25 \mu \mathrm{g}$ and $5 \mu \mathrm{g})$, upper band $\alpha$-chymotrypsinogen $\mathrm{A}$, intermediate band chymotrypsin B-chain, lower band chymotryp$\sin$ C-chain. B: SP II B albumin $(5 \mu \mathrm{g})$. C: SP II A albumin $(5 \mu \mathrm{g})$. D: SP II B albumin $(0.5,1.0,1.5$, $2.0,2.5$ and $3.0 \mathrm{ug}$ ) polymerized by glutaraldehyde. E: SP II B albumin $(2.0,2.5$ and $3.0 \mu \mathrm{g})$ and BSA $(2.0,2.5$ and $3.0 \mu \mathrm{g})$ polymerized by glutaraldehyde. 


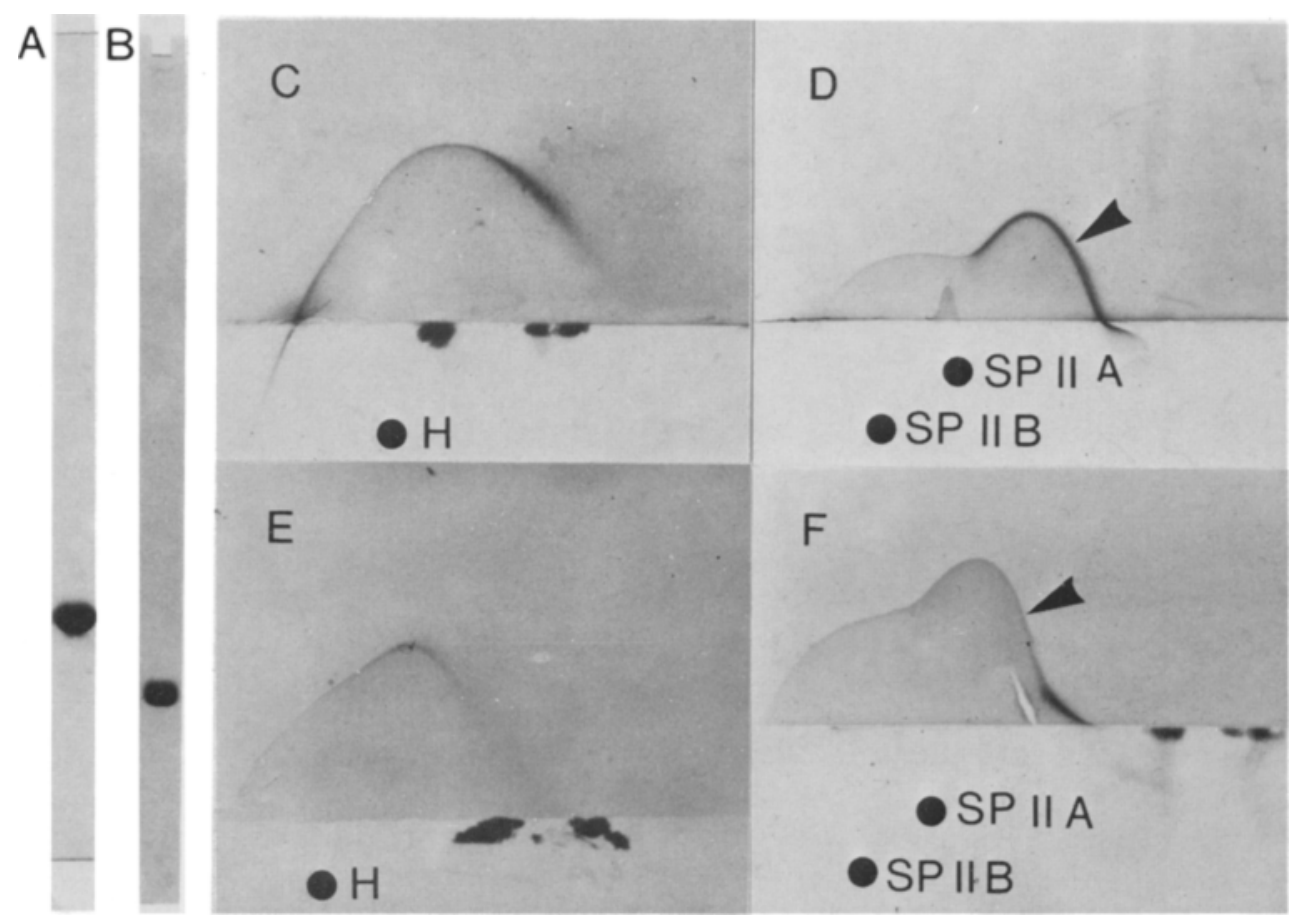

Figure 9. Purity and immunological characterisation of the SP II A and SP II B albumin protein.

A) SDS gel electrophoresis of purified SP II A protein. B) SDS gel electrophoresis of purified SP II B protein. C) Crossed immunoelectrophoresis (rabbit antiserum no. 1) of $0.010 \mathrm{ml} 5$ times concentrated crude Hiproly extract (section 2.6) applied in the antigen well H. D) Tandem crossed immunoelectrophoresis (rabbit antiserum no. 1) of $0.010 \mathrm{ml}(20$ microgram) of SP II A and SP II B protein, respectively. E) Crossed immunoelectrophoresis (rabbit antiserum no. 8) of 5 times concentrated $0.010 \mathrm{ml}$ crude Hiproly extract (section 2.6). F) Tandem crossed immunoelectrophoresis (rabbit antiserum no. 8) of $0.010 \mathrm{ml}$ of SP II A and SP II B protein, respectively.

B protein. This result was not unexpected as it is known that it is difficult to produce antisera against low molecular weight proteins. A successful method has been developed by BoLLUM (4) who obtained good antigen response by crosslinking small protein antigens to themselves and to bovine serum albumin (BSA) with glutaraldehyde. The method of Bollum (4) was chosen in this work, and two rabbits were immunized with crosslinked SP II A proteins and five rabbits with crosslinked SP II B protein. In addition two rabbits were immunised with antigen crosslinked to BSA. Two different immunization schedules were followed; the immunization procedure is outlined in Table III. The polymerizations were checked by SDS gel electrophoresis. Well defined dimers and trimers were observed in the polymerized SP II A and SP II B preparations. In the SP II A and SP II B preparations polymerized in the presence of BSA, SP II A and SP II B dimers, trimers and undefined SP II A-BSA and SP II B-BSA polymers were observed, respectively (Figure 8).

The antisera obtained from rabbits $2,3,7$, and 8 (Table III) produced one faint immunoprecipitate arc when used for crossed immunoelectrophoresis (Figure 9E) against a crude Hiproly extract. Antiserum from rabbit no 1 gave likewise one arc, but of superior intensity (Figure 9C). Tandem crossed immunoelectrophoresis was performed with each of the five antisera against purified SP II A and SP II B protein. Rabbit sera 2, 3, 7, and 8 produced two fused immunoprecipitate arcs against the two antigens 
indicating immunological identity between SP II A and SP II B (Figure 9F). A similar situation was found for antiserum no. 1, but the immunoprecipitate developed against the SP II A was much stronger (Figure 9D arrow) than the immunoprecipitate produced by the four other antisera against SP II A (e.g. Figure 9F arrow). The small arc inside the large immunoprecipitate of Figure 9D could not be detected reproducibly and is considered an artefact. Crossed immunoelectrophoresis reveals the presence of SP II A and SP II B proteins in the crude extract of Hiproly. The asymetric shape of the arcs indicates the presence of at least two electrophoretically different, but cross-reacting proteins.

The limited resolution is probably due to the closely spaced isoelectric points and the relatively high diffusion rate of the two proteins due to their low molecular weight.

Tandem crossed immunoelectrophoresis versus the two purified high-lysine proteins displayed immunochemical identity. However, one antiserum (no. 1), produced against the larger of the two proteins, reacted preferentially with this protein (SP II A), indicating that rabbit no. 1 had identified specific antigenic sites on the SP II A protein where the other rabbits had failed. Consideration of the immunological identity between SP II A and SP II B, the additional antigenic sites on SP II A, together with the amino acid analyses of these proteins leads to the suggestion that SP II B is a fragment of the SP II A protein: The primary structure of these two high-lysine proteins will be considered in a later paper.

\section{ACKNOWLEDGEMENTS}

I wish to express my sincere gratitude to Dr. L. Munck and to Dr. T. NiLsson-Tillgren for support and encouragement and to Dr. G. GrbBons and professor D. von WeTtSTEIN for their assistance in preparing this communication and to Lic. Tech. B. S. ENEvoldsen for performing the carbohydrate analyses. I am indebted to METTE Høu for her excellent technical assistance and pleasant collaboration. I am most grateful to Dr. J. HEJGẢRD, Department of Biochemistry and Nutrition, Technical University of Denmark, Lyngby, for advice and guidance with the immunological part of the work.

\section{REFERENCES}

1. ANDREws, P.: Estimation of molecular size and molecular weights of biological compounds by gel filtration. Methods Biochem. Anal. 18, I-53 (1970)

2. Axelsen, N. H., J. Krøll \& B. Weeke (eds.): A manual of quantitative immunoelectrophoresis. Methods and applications. Universitetsforlaget. Oslo (1973)

3. Benze, W. L. \& K. Schmid: Determination of tyrosine and tryptophane in proteins. Anal. Chem. 29, 1193-1196 (1957)

4. Bollum, F. J.: Antibody to terminal deoxynucleotidyl transferase. Proc. Nat. Acad. Sci. U.S.A. 72, 4119-4122 (1975)

5. Bull, H. B., K. Breese, G. L. Ferguson \& C. A SWENSON: The pH of urea solutions. Arch. Biochem. Biophys. 104, 297-304 (1964)

6. Chua, N.-H. \& P. Bennoun: Thylakoid membrane polypeptides of Chlamydomonas reinhardti: Wild type and mutant strains deficient in photosystem II reaction center. Proc. Nat. Acad. Sci. U.S.A. 72, 2175-2179 (1975)

7. Dubors, M., K. A. Gill.es, J. K. Hamilton, P. A. ReBers \& F. Smith: Colorimetric method for determination of sugars and related substances. Anal. Chem. 28, 350-356 (1956)

8. El-Negoumy, A. M., C. W. Newman \& B. R. Moss: Chromatographic fractionation and composition of the components of the salt-soluble proteins from Hiproly (CI 3947) and Hiproly normal (CI 4362) barleys. Cereal Chem. 54. 333-344 (1977)

9. HARBOE, N. \& A. INGILD: Immunisation, isolation of immunoglobulins, estimation of antibody titre. In: A manual of quantitative immunoelectrophoresis. Methods and applications. N. H. Axelsen, J. Krøll \& B. Weeke eds., Universitetsforlaget Oslo, pp 161-164 (1973)

10. Helm, J. H., R. J. Metzer \& W. E. Kronstad: Inheritance of high lysine in Hiproly barley and its association with the Hiproly endosperm gene. Crop Sci. 14, 637-640 (1974)

11. Hirs, C. H. W.: Determination of cystine as cysteic acid. Meth. Enzymol. 11, 59-62 (1962)

12. Ingversen, J. \& B. KøIE: Lysine-rich proteins in high-lysine Hordeum vulgare grain. Phytochemistry 12,1107-1111 (1973)

13. INGVERSEN, J. \& B. KøIE: Lysine-rich proteins in the salt-soluble protein fraction of barley. Phytochemistry 12, 73-78 (1973) 
14. JONASSEN, I.: Characteristics of Hiproly barley II. Quantification of two proteins contributing to its high lysine content. Carlsherg Res. Commun. 45. 59-68 (1980)

15. Mikola, J., M. Nummi \& T.-M. Enari: Effects of standing on the protein extracts of barley grain. Nature 195, 808 (1962)

16. MuncK, L.: Barley seed proteins. Symposium on seed protein synthesis properties and processing (Los Angeles. California). Amer. Chem. Soc. (Ed.) G. E. Inglett Avis Publ. Co. (1972)

17. MUNCK, L.: Improvement of nutritional value in cereals. Hereditas 72, 1-128 (1972)

18. Munck, L., K.-E. Karison, A. Hagberg \& B. O. EGgum: Gene for improved nutritional value in barley seed protein. Science 168, 985-987 (1970)

19. Neville, D. M. Jr.: Molecular weight determination of proteindodecyl sulfate complexes by gel electrophoresis in a discontinuous buffer system. J. Biol. Chem. 246, 6328-6334 (1971)

20. Osborne, T. B.: The proteids of barley. J. Am. Chem. 17, 539-567 (1895)

21. Pomeranz, Y., D. M. Wesenberg; R. T. Smith, G. S. Robiins \& J. T. Gilbertson: Amino acid composition of barley kernels from different parts of the spike. Cereal Chem. 53, 839-845 (1976)

22. Strgbeк, S. \& G. C. Gibbons: Ribulose-1,5diphosphate carboxylase from barley (Hordeum vulgare). Isolation, characterization, and peptide mapping studies of the subunits. Carlsberg Res. Commun. 4l, 57-72 (1976)

23. $\mathrm{Ur}, \mathrm{N}$.: Isoelectric points and conformation of proteins. I. Effect of urea on the behavior of some proteins in isoelectric focusing. Biochim. Biophys Acta 299, 567-581 (1971) 